\title{
The Research of Promoting the Chinese Banking Industry Core Competitiveness under the Financial Globalization Background
}

\author{
Jingting Ma \\ School of Graduate, Shenyang University \\ Shenyang 110041, China \\ E-mail: tkk1lt@126.com \\ Jing Sun \\ School of Business Management, Shenyang University \\ Shenyang 110041, China \\ E-mail: sunjing9819@yahoo.com.cn
}

\begin{abstract}
Along with the Chinese financial market unceasing opening, the financial globalization tendency develops thoroughly, various countries financial market relation is closer, the internationalization degree enhances day by day. The financial innovation and the comprehensive management tendency develop unceasingly, between various professions seeps mutually. The international finance competition is more and more intense; the capital interstate flowing scale expands unceasingly, the element of certainty increases. If Chinese banking industry wants to survival and develop in the competition environment, only then promotes its financial innovation ability, according to the market demand change and own business development condition, promotes the financial product which can satisfy the customer and the market demand unceasingly, can expand the market share unceasingly, is in an impregnable position in the intense market competition.
\end{abstract}

Keywords: Chinese Banking industry, Financial globalization, Core competitiveness

\section{The Chinese banking industry is facing the challenges}

After China to join World Trade Organization transition-period had finished, the banking industry competition is more intense. Under this new situation, the Chinese Banking industry not only has the new development opportunity, but also faces a more stern challenge; it is in the important transition and the development time.

\subsection{International finance environment}

Since 2008, the external environment of Chinese Banking industry developed faced the aspect which worsens with the short-term. The American secondary loan crisis, the energy and the international bulk commodity raise in price causes the world economics to fall into the difficult position which the economic growth to postpone and the inflation in a short time.

\subsubsection{Global inflation threat aggravating}

Influence of the petroleum and the price raising, global resident consumer price indices CPI comprehensive rise since 2008. The US announces the data demonstrated that this country y CPI in May rises $4.2 \%$ than same time of last year, is the highest rise since January this year, core CPI has risen 2.3\% than same time of last year. The European Union Statistics bureau issued the newest data demonstrated that the Euro zone currency inflation rate was once continual for 9 months to break through the European Central Bank 2\% warning lines which establishes for maintenance price stability, currency inflation rate is that dramatic rise to $3.6 \%$ in May of 2008; The Russian April's CPI index already achieved $14.5 \%$, creates highest level in the recent 5 year; the Vietnamese currency inflation rate reaches as high as $25.2 \%$ in May of 2008, Indonesia surpasses $10 \%$, Philippines is $9.6 \%$, India surpasses $8 \%$, Thailand is $7.6 \%$, South Korea is $4.9 \%$.

\subsubsection{International financial industry risk increases}

The international Financial market will have the fierce turbulence in recent, the financial risk appears frequently. Take the American secondary loan crisis eruption as the symbol, the global economic entered the deceleration cycle. The American secondary loan crisis starts appear gradually from spring of 2006, it has swept across world main financial market and so on US, European Union and Japan since 2007 August. The US real estate market is also continuing at present to worsen at present, the financial market is unstable, the employment reduction and unemployment increases, the resident expected income to reduce, the consumer confidence to drop, the consumption expenditure growth to 
stagnate, the contraction of credit, the investor confidence to suffer setbacks, the fixed capital forming to drop, the influence of loan crisis is further also deepening. But Vietnam financial crisis will highlight will possibly become the new round southeast financial crisis's blasting fuse. The French Bank cheat document once more has demonstrated the financial industry risk management importance.

\subsection{Domestic financial environments}

1.2.1 The risk of economical periodicity fluctuation is accumulating, bank asset quality faced with new test

The periodicity fluctuation is the economy moves inevitable regular performance.

As the emerging market economy system, China already experienced to continue fast growth more than 30 years, while the economy high speed steady progression, also accumulated such as the development imbalanced as well as the environmental pollution and so on, the economical periodic fluctuation risk is accumulating. Therefore, the Chinese industry, the profession as well as the economic structure are experiencing the huge adjustment. This kind of adjustment in the long run, no doubt has the great importance significance to the economical finance health sustained development, but looked from the short-term, the economic regulation possibly bring the new risk to the bank management, specially the tight monetary policy environment which take suppresses the inflation as the goal, as well as the strict environmental protection and energy conservation adjustment, will bring the development management pressure to the bank and faces the credit pattern readjusting, but the significant assets structure adjustment can cause the Commercial bank faced with the property quality worsens possibility.

1.2.2 Commercial banks will experience "the finance to escape the intermediary" and the interest rates liberalization dual converging attack, the Profit gap will squeeze.

In China, the interest rates liberalization already realized in the wide range, at present only has the standard currency to save the rate on loan maintenance control interest rate. In order to compromise the pledge when China joined World Trade Organization, the standard currency saves the rate on loan also to realize the marketability in the near future, the direct result that will be the bank saves the loan spread to squeeze. This will form the serious survival threat to Commercial bank which the tradition save and loan service primarily, the interest risk will also become the most main operational risk which Chinese Commercial bank will face from now on. Meanwhile, the capital market will obtain the further policy to encourage and to support, realizes a quicker development. In the bond market development in the increased speed foundation, markets and so on stock, fund, and commodity forward business will speed up the development step, the securities business and the insurance business development lag in banking industry's aspect will have the very big improvement. The international banking industry experienced the finance to escape the intermediary painful process in the last century 70-80 ages. The experience formerly indicated that the finance will escape the intermediary tendency proposed the stern survival challenge to the Commercial bank tradition modes of business operation and the structure, will cause the Commercial bank to face the bankrupt risk generally. Implements mixes industry management is main method and the way which the international Commercial bank gets rid of the survival threat which the finance to escape the intermediary brings. And, in China, the finance will escape the intermediary and the interest rates liberalization tendency will interweave in the same place, the interest rates liberalization will cause the bank spread will reduce tendency will intensify the speed and the scope of the finance to escape the intermediary.

\subsubsection{Comprehensive opening bring the enormous challenge for the Chinese-funded bank.}

China joined World Trade Organization transition-period already to finish, the domestic financial market opening assumed comprehensive and acceleration aspect, the foreign capital financial organ enters crowded, moreover even more paid great attention the strategic investor who fused into the domestic bank through the capital, gained the financial service network and the customer resources quickly. The domestic financial market's competition was evolving fast for the difference between the Chinese and foreign capital financial organ alliance organization competition, the competition pattern has had the comprehensive deep transformation, formed the serious challenge to the Chinese-funded bank.

\section{Chinese banking industry development present situation}

The recent several years, Chinese Bank competitive power really has been promoted. No matter is the capital sufficiency of capital and the property quality, gains aspects and so on ability and fluidity managed capacity has the distinct improvement. More importantly, the majority Commercial banks established the capital to supplement mechanism and saved use capital idea, established good risk management system which has enabled the property quality to guarantee even enhanced and promoted bank strategy reforming, service reforming and the profit pattern transformation which adaptation environmental variation and customer demand change positively. State-owned bank through reform going on the market reproduction vigor, original joint stock system Commercial bank to maintain the competitive advantage further promotes own competitive power through the internal reform, the city Commercial bank through the dyspepsia property, increases funding expands stock methods and the way and so on alliance, cross region management as well as going on the market, is clear about the management localization, launches the comprehensive 
competition with each kind of Commercial bank in many domains. But, Chinese Commercial bank competitive power's remarkable enhancement cannot cover the existence question, mainly concentrates in five aspects:

\subsection{The mechanism of the company governs and internal controls not to be still imperfect}

Through the bank remanufacture and going on the market, Chinese Bank Company governs has the improvement, but the subject of investment multiplication degree is still somewhat low, authority to keep in balance system validity to be bad, also cannot guarantee the trustee, the supervisor and high level managers assiduous fulfilling duty, also cannot achieve strictly accountability system to the significant dereliction of duty personnel. The higher managements seek the personal interest using the bank asset, causes the shareholder rights and interests not to be able to obtain the effective protection; The major stockholder using methods and so on connection transaction seeks the improper income, even endangers to the bank operational; The independent director becomes a mere formality phenomenon to be common, many banks only hope to use their popularity and the old relational display role, the improvement of governs to the company not to play the substantive function. After Commerce bank, Construction bank, Communications Bank and Bank of China stock reform going on the market, reforms to the depth advancement duty is also very arduous. The completely responsible phenomenon also is very specially common by "the chief leader" in the Branch office, lacks essential keeps in balance mechanism, in addition legal person organization decision-making control is limited, the branch office does not carry out, causes the basic unit organization illegally contrary, the major event serious case sometimes occurs.

\subsection{The account executive and the source of income is still unitary}

Although Chinese commercial bank non-interest return proportion rises with steady steps, but financial innovation ability low question not radically solution. Even if in the Asian and Pacific area, Chinese commercial bank non-interest return is also at the inferiority position compares with other foreign bank. For example, the non-interest of Japanese Tokyo Mitsubishi Bank and Australia National bank non-interest return respectively achieves $56.6 \%$ and $44.4 \%$ in 2006 , but the same time China ICBC is only $8.8 \%$. Causes this kind of pattern is because various reason: First, Chinese Commercial bank is been microscopic intervention serious by all levels of the government for a long time, monopoly management, contents with the status quo, neglects development to the new service variety, causes the business of banking scope to be narrow. Next, is supervised system influence, China legal rule that Commercial bank can only be engaged in the business operating at a liability, the asset operation, but cannot look like the overseas bank such to provide including the loan, the settlement, the consultation, the investment, the proxy insurance and the trust investment "the supermarket service", causes the bank finance variety to be monotonous.

\subsection{The high-end talented person who matches with the modern bank enterprise is still deficient}

The Commercial bank is the knowledge intelligence intensity industry; the talented person is the important support of the modern bank competitive power. Especially along with Chinese economy marketability degree unceasing enhancement, the uncertainty strengthens in the economical movement, the bank operational risk enlarges, urgent need high-end talented person manages the risk, operational risk, but the high level talent in this domain is obviously insufficient in China.

\subsection{The Commercial bank exterior living environment waits for optimizing}

First, the banking supervision validity still waited for further enhancing. Especially between the banking supervision and the financial innovation is also unable to achieve the balanced and coordinated development, the supervision level, the method relative lag, has restricted the Commercial bank competitive power enhancement. Second, the fund price receives the control. Chinese Commercial bank had already formed thought format of the interest rate, the foreign exchange fluctuation non-risk, consciousness the financial risk not to be strong on own initiative, because is unable forecast and guard risk better, causes the Commercial bank competitive power to receive weakens greatly. Third, China Commercial bank tax burden is heavy. Although the financial industry business tax rate already dropped to $5 \%$ from $8 \%$ in 2001, but looking from the global scale, the Chinese Banking industry business tax rate is the highest in the world, the majority countries do not levy in business tax, even if levies, tax rate is also $1.2-4 \%$.

\subsection{In the financial norm performance aspect, Chinese Commercial bank still had the disparity}

Because the commercial bank company governs not perfectly, financial innovation ability is limited, the high-end talented person flaw, the external environment restriction, has the influence inevitably to the financial norm. Looking from the property returns ratio, although Chinese property scale surpassed 1,000 billion RMB, the ROA level of Commerce bank, Bank of China, Construction bank, Communications Bank, businessmen bank already to surpass $1 \%$, was in the superior level in the world 1000 big banks, but to be very still big disparity compared with the international advanced level. For example the American Bank property returns ratio achieves $2.19 \%$ in 2006, but the Indonesian Banking industry property returns ratio has achieved $1.92 \%$ in 2002 , hereafter maintains at $2 \%$ above level. Looking from the capital sufficiency of capital, Indonesian, Thai, the South Korean Bank capital sufficiency of capital respectively achieves $20 \%, 13.85 \%$ and $12.31 \%$ in 2006; the Japanese 9 greatly Main bank capital sufficiency of capital 
achieves $13 \%$ equally. Looking from the non-performing loan proportion, in 2006 ,South Korea Commercial bank non-performing loan proportion already dropped to $1 \%$ below, the Japanese 9 greatly Main bank non-performing loan proportion dropped to $1.5 \%$.

\section{The Chinese Banking industry promotes the core competitiveness countermeasure}

\subsection{Initiative transformation business model and the growth way.}

Facing the pressure which the tradition loan market and the income squeeze which the domestic interest rates liberalization and "the finance to escape the intermediary" brings, the intensifies pressure which facing the international domestic competition, Chinese Commercial bank must implement the business model, the growth way and management structure strategic reforming on own initiative, develops the comprehensive management positively, the across-the-board adjustment assets structure, the service structure, the debt structure, the income structure, the customer structure, the marketing channel structure as well as the staff knowledge and the skill structure, realizes the business model by to expand by the scale primarily to by the quality benefit transformation primarily, realizes the growth way to save the loan business income by the main dependent tradition to the multiplex integration income transformation, promotion core competitiveness and the financial service level, cause the Chinese Banking industry to become the world first-class modern finance enterprise which has strong innovation ability and the international competitiveness.

\subsection{Increase the independent innovation, promotion core competitiveness}

As state-owned joint stock system Commercial bank, to deal with the intriguing international domestic condition of business, melt constitutive property and the institutional risk, promotion core competitiveness and the international competitiveness, must found the innovation bank, through advances the system, the mechanism, the management, the service and the technological innovation vigorously, impels the business model and the growth way transformation and the competitive power enhancement. Must speed up the integrated management step through the innovation, by merger and acquisition, joint capital service domains and so on way development the securities ,the insurance, establishes China own investment bank and financial holding group which has the complete service; Must complete service and the management flow transformation with steady steps through the innovation take the customer as central, take the risk control as the core, establishes the highly effective marketing team and the formidable product support system, making specialization and centralized risk management platform, completes transformation from the department bank to counter current regulation bank; Must display the finance technological innovation impetus and the support function to the service and the institutional innovations, optimization science and technology input structure, raises the technical development efficiency, enhancement introduction digestion absorbance and independent innovation ability, surpasses the international financial industry advanced science and technology level comprehensively. Moreover, along with Chinese economy and world economics integration process's quickening, foreign trade scale will expand rapidly, the international market fluctuation will strengthen unceasingly to domestic market's influence, the domestic enterprise will face the more and bigger and more directly international market risk during participation international market competition, therefore, the market will have the formidable demand to the financial derivation tool which will dodge the market risk, such as commodity futures exchange, the exchange rate option, the forward exchange transaction and so on,; The foreign capital exile scale expands, the capital market opening to the outside world and with international capital market integration process quickening unceasingly, also will initiate to the exchange rate, the currency derivation tool as well as the exchange transaction demand; For the consummation domestic Stock market, introduction option transaction is also the realistic demand. Therefore, development finance derivation tool market will become Chinese financial market development choice inevitably in the future, is also Chinese banking industry service innovation direction.

\subsection{Deal with the challenge of the Chinese banking industry comprehensive opening to the outside world positively}

The financial innovation is the Commercial bank competitive power important fountainhead. The contemporary finance product innovation has two general trends; first, standardized standard service; second, personalized financial service. In view of the former, the Commercial bank must raise the customer service self-service level diligently. In view of the latter, the Commercial bank must unify the customer concrete demand at the same time, design product and the service which has the high knowledge and the technique content, brings the great value for the customer; On the other hand, the Commercial bank must develop the remittance, the settlement, the guarantee, the proxy, the trust, the consultation, the fund trust, individual managing finances, the investment management and so on middle service vigorously, creates and forms the new profit point of growth diligently. During studies and introduces the advanced bank financial product, pays great attention to strengthen the independent innovation ability construction, sharpens the innovation product fixed price ability.

\subsection{Consummate Commercial bank's risk to control from the inside}

The Commercial bank operational risk ability as well as controls from the inside mechanism quality, immediate influence its own competitive power. In the Commercial bank risk management aspect, must realize the risk 
management scope completely: first, guarantees the risk management content universality, also includes risk each type, also contains the business scope of bank interior each level; second, guaranteed that the risk management personnel have the universality, not only dependence risk management department, must rely on to the board of directors member and each staff of bank, forms the risk management diligently culture diligently; third, guarantees the bank risk management link's integrity, not only involves the trade development each process, completes the customer admittance, to investigate before loan earnestly, in the loan examines, the loan, manages after loan and so on, must involve the service development each region, achieves effective appraisal and the early warning to the risk between the nationality and the local transformation and shift. Is consummating the bank to control from inside aspect, the key is that completes the organization restoration and the flow reorganization, speeds up realizes the service line and the level flattening, establishes the keen market reflection mechanism, the effective quality control system, the advanced risk and cost control ability, through widespread, diverse marketing channel and overlapping sale, provides quickly, satisfaction integrated management service for the customer.

\subsection{Raise the bank informational level unceasingly.}

The informational level is also weighs the Commercial bank competitive power height the important symbol. The modern bank's competition, in some kind of degree says, was one modern technology competition; the technology first has created the superiority with the information forerunner for the bank competition. It can be said that the present information technology's progress and the modern bank's development is the relations which promotes mutually. Since the 1990s, has obtained the swift development take the Internet as representative's information technology, simultaneously has had the major impact on the world economics, this is so-called "the new economy" the phenomenon. "the new economy" while is raising the labor productivity, to promote world economic development enormously, also has formed the huge challenge to the traditional economy. First, "the new economy" to the traditional economy's impact manifests, to already has the market to compete on. The Internet has the superiority which the traditional media is unable to compare, can take a quicker speed, in bigger range provide the convenient service as the large-scale customer. Relies on its superiority, the Internet enterprise corrodes the Traditional enterprise gradually the market share which only then strives for diligently through many years. In the financial industry this kind of service industry, Internet's superiority manifests the outstandingly. As has more than 100 year historical American fifth big bank Morgan Banks, also intimate understanding "new economy" impact. The Morgan Bank primary service domain is grows the negotiable securities the transaction and the risk management. The customer and the cost are its establishment competitive advantage most important factors. But will carry on these services on the Internet to be easier to contact the general small client base, but can also the large curtailment of service cost. On the other hand, "the new economy" is also competing for the intelligence resources with the traditional economy. Internet enterprise's large amount risk capital investment, the nimble assignment system as well as are unable in the Traditional enterprise to realize the undertaking excitement, attracts these most to be having the entrepreneur who innovative spirit joins in "the new economy" in the flood tide. The west some developed Commercial bank in has paid attention to and the research Internet technology to the traditional financial industry influence, the research demonstrated that the tradition financial organ can profit at least in four aspects from the Internet technology application: 1 is advantageous to the financial service innovation; 2 are advantageous in enhancing the financial service the efficiency; 3 are advantageous in winning more customers; 4 are advantageous in cutting the cost of operation.

\subsection{Establishment the perfect science effective motivation and restraint mechanism}

Profits from the international advanced experience, constructs the new human resources management system, speeds up establishes a new human resources management system which staff and the enterprise communal development, the motivation and restraint effective. Through implementation the staff owns stocks plan reform in the ordinary staff, stresses the employee benefits, transfers the staff activity effectively, to display their creativity; implementation stockholder's rights drive system to the high level managers, guaranteed that the high managers maintain consistent with the bank overall benefit, avoids the policy-making behavior short-term.

\subsection{Pay great attention to optimize the external environment of bank competitive}

Strengthens the commercial bank company to govern and supervision, supervision Commercial bank improves and consummates the management and operation system and the organization mechanism, through further enriches and consummates the supervision laws and regulations system, promotion Commercial bank competes reasonably. Advances the comprehensive management experiment site with steady steps under the minute industry supervision frame, is further clear about the Commercial bank product innovation scope, announcement encourages the product name list which the Commercial bank develops as well as forbids the product name list which the Commercial bank develops, in view of the product which do not in detailed list scope, carrying out permission Commercial bank advance development system. Strengthens to the Commercial bank finance innovation intellectual property protection, further transfers the Commercial bank finance innovation enthusiasm. Refers to the international standard, coordinated finance and taxation department, lowers the bank tax burden level. 


\section{References}

Jiguang Zhang. (03, 2008). "The city Commercial bank develops: reviews in 2007 and forecast in 2008", Banker.

Mi zhou, Min Ge. $(02,2007)$. The choices of the core competitiveness of Commercial bank finance innovation way research. Business Research.

Molyneux, Shamu Locker. (2003). The finance innovates. Beijing: China Renmin University publishing house.

Qiong Wun. (05,2007). The Commercial bank finance innovation's way chooses. Modern Commercial.

Yafei Wei. (06, 2006). Discussed how to enhance Commercial bank independent innovation ability. Heilongjiang Finance. 